\title{
Impact of Ultimate Ownership Type on Audit Fees with Corporate Governance as Moderating Variable
}

\author{
Andina Vivandari \\ Department of Accounting \\ Faculty of Economics and Business, Universitas Indonesia \\ Depok, Indonesia \\ andina.vivandari97@gmail.com
}

\author{
Fitriany Fitriany \\ Department of Accounting \\ Faculty of Economics and Business, Universitas Indonesia \\ Depok, Indonesia \\ fitrianyamarullah@gmail.com
}

\begin{abstract}
This study examines the impact of ultimate ownership type on audit fee and corporate governance role as moderating variable, using banking companies data from 2012-2016. Results show that ultimate family ownership had no significance impact to audit fees due to alignment effect and entrenchment effect. However, institutional ownership had a significant positive effect on audit fees because institutional investors demand high quality external audits as a form of investor protection. Government ownership has a significant negative effect on audit fees only with moderating variables because government ownership increases the company's control (alignment effect) and reduces its risk. This study also found that the role of the board of commissioners and the audit committee did not moderate the effect of ownership on audit fees.
\end{abstract}

Keywords- audit fee, ultimate ownership, corporate governance

\section{INTRODUCTION}

The type of shareholding structure, that is, concentrated or dispersed ownership in a company, can cause agency problems of two types [1]. Agency type I problems occur between the shareholders as principal and the management as the agent that runs the company; the second type emerges between majority and minority shareholders. Agency type I problems often occur in companies with scattered ownership, but in companies with concentrated ownership, agency type II problems arise because of the possibility of expropriation by majority shareholders becoming problematic for minority shareholders. In family-owned companies, Villalonga and Amit [2] observed strong incentive for major shareholders to expropriate the company from minority shareholders, using the control position to take personal advantage. Possible agency problems, either type I or type II, can affect the demand for external audit services, with independent audit becoming a corporate governance mechanism to mitigate agency problems and information asymmetry. Of course, auditing fees are a component of monitoring cost [1]. The more agency problems, the more auditor time spent and the higher the audit fee.

In Indonesia, the majority of companies are familyowned [3], and expropriation from minority shareholders can certainly occur. To provide assurance of high quality corporate governance, a company performs good monitoring and also strives to obtain a high quality audit that functions as insurance for shareholders and reduces agency costs.

Two arguments can explain the effect of concentrated ownership. The first implies that concentrated ownership increases shareholders' supervision so that oversight is more effective because of the amount of incentives to protect the company's reputation and keep it going. Such effective supervision and maintenance of reputation affect the audit fee charged.

Another argument implies that concentrated ownership increases risk of expropriation of minority shareholders [4]. Therefore, investor protection is crucial [5], and one kind is external audit services that serve as insurance for stakeholders' demanding external audits due to high risk of expropriation. However, such expropriation risk might also result in decreased audit fees because the company can choose a cheap, easily influenced public accounting firm to cover its expropriation.

This research continued the research of Khan, Muttakin, and Siddiqui [6] who examined family ownership's relation to audit fees. But this study examined the relationship of family, institutional, and government ownerships with audit fees, adding institutional and governmental ownership variables to the previous study's design. To determine the effect of corporate organs on supervision of audit fees, this study added the variables of the role of the commissioners and audit committees in moderating ownership variables. In earlier research, ownership and audit fees were at least influenced by the role and effectiveness of corporate organs, such as boards of commissioners and audit committees [4].

This research was conducted on public companies in the banking sector because of the absence of such studies on the effect of ownership on audit fees in this sector. Banking companies disclose their ultimate ownership in reports to Bank Indonesia (BI) and Otoritas Jasa Keuangan (OJK). In this research, ultimate ownership was used as the variable of operationalization. Important to note is that the BI and OJK's special applied regulations for banks causes this sector to have corporate characteristics that differ considerably from non-banking 


\section{LITERATURE REVIEW}

\section{A. Ultimate Ownership's Relationship to Audit Fee}

Family ownership relationship to audit fee offers two directions of argument, entrenchment effect and alignment effect.

Entrenchment effect occurs when there is expropriation risk. Family ownership with a percentage greater than $33 \%$ shows greater tendency to expropriation [4]. In familyowned corporations, the controlling shareholder has strong control over a high percentage of voting rights and thus has strong incentives to exploit minority shareholders [2]. Compared with non-family owned companies, family firms face a lower type I agency and a higher type II agency because of issues between controlling and minority shareholders [7]. Such expropriation risk increases required audit effort and raises audit fees. However, Khan, Muttakin, and Siddiqui [6] found that expropriation suppresses audit fees. Too, expropriation is accomplished by the shareholders' choosing an independent member of the board of directors who is aligned with the controlling shareholder. Then, the company uses a cheap external audit service and chooses an easily influenced Kantor Akuntan Publik (KAP) to cover the expropriation that has occurred.

Darmadi [8] states that companies with concentrated ownership prefer to use audit services from the Big 4 public accounting firms (Deloitte \& Touche, Ernst \& Young, KPMG, and PricewaterhouseCoopers) to produce quality audits that mitigate agency problems, signal stakeholders that companies are doing well, and maintain the company's reputation. However, in companies whose controlling shareholders are family, the relationship becomes negative through employment of low quality auditors. Because the audit effort is considered unnecessary and does not affect the company's sustainability, it does not require a high audit fee.

Another argument, the alignment effect, states that family ownership has negative impact on audit fees. Ben Ali and Lesage [9] found a negative relationship between family ownership and audit fees due to family shareholders' participation in supervision of company management minimizing agency problem type I so as to reduce risk. However, to maintain reputation, family shareholders might also choose to use quality external audits to attract investors and as insurance for stakeholders so that the audit fee increases.

Based on the argument above, this study predicts that ultimate family ownership affects audit fees. This prediction takes two directions because expropriation risk and effective supervisory incentives affect a two-way audit fee. Therefore, the first hypothesis can be formed as follows:

\section{H1: Ultimate family ownership affects audit fee.}

A second type of ownership is institutional. Ben Ali and Lesage [12] and Mitra, Hossain, and Dein [10] found a positive relationship between institutional ownership and audit fees. Institutional investors demand specific quality information as insurance against their investments, so they also demand good quality audits, which raises audit fees. However, Alqadasi \& Abidin [11] found that institutional ownership sparked earnings management in banking companies due to the institutional environment's weakness, thus opening opportunities for expropriation. Risk of expropriation and earnings management increase audit fees. However, different results were found by Khan, Muttakin, and Siddiqui [6] who conducted research in Bangladesh, where lack of market efficiency led to lack of corporate incentives to conduct quality audits, so audit fees were low.

This study predicts a positive effect of institutional ownership on audit fees. Based on World Bank data from the Report on the Observance of Standards and Codes (ROSC), the index of investor protection in Indonesia is quite good, with values above the Organisation of Economic Cooperation and Development average and the value of other Southeast Asian countries. As a form of protection against third parties whose funds are managed by institutional investors, institutional investors demand quality external audits to ensure accurate information and the absence of expropriation so that external audit requests rise. According to signaling theory, institutional investors signal to thirdparty fund owners that the company is performing well through a good external audit that also raises audit fees. Therefore, a second hypothesis can be formed as follows:

$\mathrm{H} 2$ : Institutional ownership positively affects audit fee.

Several arguments posit a negative relationship between government ownership and audit fees. Ben Ali and Lesage [12] state that the proportion of government ownership pressures companies with agency problems. To protect its reputation, the government has an incentive to be active in oversight. If the government fails to protect the company's reputation, it experiences loss via reputation costs. Ben Ali and Lesage [12] believe that government ownership signals the market that there is no expropriation, so risks and audit fees are low.

Several other studies have found different results. Wang et al. [4] found that firms' audit fees are low because they use local auditors or small KAPs because they are easily influenced and audit fees might be lower. Too, this facilitates manipulation of financial statements and gives the impression of a good reputation. The incentives for such manipulation are political and social [11].

Meanwhile, Nelson and Rusdi [13] found a positive relationship between government ownership and audit fees. The possibility of a conflict of interest between the government and the company can increase agency problems, thus raising the required audit effort and its resulting fee.

This study predicts a negative influence of ultimate government ownership on audit fees because the government has greater incentive to supervise: It bears reputation costs if the company has problems. Therefore, the third hypothesis can be formed as follows:

H3: Government ownership negatively affects audit fee.

\section{B. Effect of the Board of Commissioners on Ownership and Audit Fee}

Both positive and negative arguments are made about relationships that influence the effectiveness of the board of commissioners in relation to audit fees.

As a supervisory function, the board of commissioners is responsible for oversight including quality control of financial statements and establishing controls related to the 
company's strategic risk. Effective oversight can mitigate potential agency problems. From a substitution theory perspective, the independence of the board of commissioners can suppress the need for an external audit because of strong supervision by the board of commissioners [14]. Collier and Gregory [15] also observed that the greater the board's number of members the more effective the Chief Executive Officer's control and oversight, thereby suppressing the need for external audits.

However, studies show that greater independence of the board of commissioners is associated with increased need for external audits $[16 ; 17]$. From the complementary theory perspective, an independent board of commissioners strives to provide insurance to shareholders and executes good oversight. Additionally, the number of commissioners significantly affects the likelihood of fraud in financial statements [18] because a large number can reduce supervisory effectiveness, thereby increasing audit effort due to potential risks incurred and thus raising audit fees.

In family firms, the role of the commissioners and audit committees is needed to protect the company in the long term [6]. The effectiveness of the board of commissioners' oversight is complemented by external corporate governance mechanisms in the form of external audits. To complement oversight, both internally and externally, the demand for high quality audits increases.

An audit committee functioning under the board of commissioners' supervision enhances corporate financial governance. An audit committee might increase audit fees to protect the company's reputation and provide insurance [14] and found that audit committee independence had a positive effect on audit fees. Goodwin-Stewart and Kent [17] and Lifschutz, Jacobi, and Feldshtein [20] found that the number of audit committee meetings also had a positive effect on audit fees.

To complement oversight, demand for high quality audits is required as an external mechanism. Chen, Kao, and $\mathrm{Lu}$ [21] argued that internal and external corporate governance mechanisms can mitigate the negative effects of ownership concentration on firm performance. In companies with concentrated ownership, external audits become a kind of insurance for investors to avoid expropriation. However, the research of Abdallah and Ismail [22] found that good corporate governance is not required in companies with high concentrations of ownership because concentration can replace the supervision of corporate organs.

This study predicts that the effectiveness of the board of commissioners and audit committees weakens the negative impact of ultimate family ownership on audit fees. Expropriation risks that might arise from concentrated ownership makes the role of the board of commissioners important to stakeholders. Supervision by the board of commissioners raises audit fees, but the company uses qualified external audit services as insurance to signal stakeholders that the company is doing well.

Therefore, this study predicts the fourth hypothesis:

H4: The effectiveness of the board of commissioners and audit committee weakens the negative effect of ultimate family ownership on audit fees.

Furthermore, this study predicts that the role of the commissioners and audit committee strengthens the positive impact of ultimate institutional ownership on audit fees. Institutional ownership is predicted to have a positive effect on audits as a signal to third-party fund owners, whose funds are held by institutional investors, that the company is doing well. The role of the board of commissioners complements the company's signals to stakeholders, including third-party fund holders by using quality external audit services.

Therefore, this study predicts the following fifth hypothesis:

H5: The role of the commissioners and the audit committee strengthens the positive effect of ultimate institutional ownership on audit fees.

In addition, this study predicts that the effectiveness of the board of commissioners and the audit committee weakens the negative impact of government ownership on audit fees. This prediction aligns with the prediction in H4. The board of commissioners provides stakeholders with assurance that the company is doing well. Ultimate government ownership allows for risk of manipulation for political purposes. Therefore, the board of commissioners needs to provide the company independent oversight to avoid such risks by using qualified external audit services as a form of insurance.

Therefore, this study predicts the following sixth hypothesis:

H6: The effectiveness of the board of commissioners weakens the negative influence of ultimate government ownership on audit fees.

\section{METHODOLOGY}

\section{A. Research Design}

This study examines the effect of ultimate ownership and corporate governance on audit fees by testing the six hypotheses stated in the previous section. The investigation is causal, that is, examines the causal relationship between the independent and dependent variables. The researcher did not manipulate any of the data. The unit of analysis was a banking company listed on the Indonesia Stock Exchange, with longitudinal data collected from 2012 to 2016.

\section{B. Research Model}

This research model replicates that of Khan, Muttakin, and Siddiqui [6] with some modifications, that is, focusing on the effect of a banking company's ultimate ownership on audit fees. In Khan, Muttakin, and Siddiqui [6], however, ownership was limited to family ownership. To this study, the researcher added institutional and government ownership variables to provide more comprehensive results. Moreover, the operationalization of variables comes from ultimate ownership. The first model tests hypotheses 1, 2, and 3 .

\section{Model 1:}

\section{AUDFEEit $=\beta 0+\beta 1$ FAMDUMit $+\beta 2$ INSTDUMit $+\beta 3$ GOVD $\mathrm{UMit}+\beta 4 \mathrm{CGit}+\beta 5$ SIZEit $+\beta 6 \mathrm{NPLit}+\beta 7 \mathrm{ROAit}+\beta 8 \mathrm{LOSSit}+\beta 9$ $\mathrm{BIG} 4 \mathrm{it}+\varepsilon$}

The next model further develops past studies related to family, institutional, and government ownership of audit fees to investigate the effectiveness of the board of commissioners and audit committee as corporate governance against audit fees. Models 2, 3, and 4 test the role of the 
commissioners as a moderating variable in relationships between ultimate ownership and audit fees. Model 2 tests hypotheses 4,5 , and 6 .

\section{Model 2:}

AUDFEE $=\beta 0+\beta 1$ FAMDUMit $+\beta 2$ INSTDUMit $+\beta 3$ GOVDU Mit $+\beta 4$ CGit $+\beta 5$ FAMDUMit*CGit+ $\beta 6$ INSTDUMit*CGit $+\beta$ 7GOVDUMit*CGit $+\beta 8$ SIZEit $+\beta 9$ NPLit $+\beta 10$ ROAit $+\beta 11$ LO $\mathrm{SSit}+\beta 12 \mathrm{BIG} 4 \mathrm{it}+\varepsilon$

where AUDFEE $=$ Audit fee $\|$ FAMDUM $=1(0)$, if the ultimate owner is(is not) family $\|$ INSTDUM $=1(0)$, if the ultimate owner is(is not) institutional investor $\|$ GOVDUM = $1(0)$, if the ultimate owner is(is not) government $\| \mathrm{CG}=$ Total score of effectiveness of the board of commissioners and audit committee $\|$ SIZE $=$ Company size $\|$ NPL $=$ Percentage of non-performing loans $\|$ ROA $=$ Return on asset $\|$ LOSS = Dummy variable, $1(0)$ if the company suffers a loss (profit) in the year $\|$ BIG4 = Dummy variable, 1 (0) if the company is audited (unaudited) by Big 4.

\section{Variable Operationalization}

\section{1) Audit Fee}

AUDFEE is measured using the natural audit fee logarithm. In 2012, Bapepam-LK issued a decision of the Chairman of Bapepam and Financial Institution no. KEP431/BL/2012 concerning Submission of Issuer's Annual Report or Public Company stating that public companies are obliged to disclose fees paid to professional services supporting the capital market, one of which is audit fees. Audit fee data was collected from the company's annual reports.

\section{2) Ultimate Ownership}

La Porta, Lopez-de-Silqnes, and Shleifer [22] declared ultimate ownership to occur when shareholders' direct and indirect voting rights exceed $20 \%$. To reveal ultimate ownership, La Porta, Lopez-de-Silqnes, and Shleifer [23] traced the chain of ownership to those with the most voting rights. In this research, we collected ultimate ownership data from BI and OJK'S reports. This variable is a dummy.

- Ultimate Family Ownership

In this study, ultimate family ownership is measured by whether the ultimate ownership of shares belongs to the family or not, i.e., all individuals and private companies, except for the state, financial institutions, public companies, and the public [23]

- Ultimate Institutional Ownership

Ultimate institutional ownership is operationalized by ownership held by financial institutions (e.g., investment institutions, cooperatives, insurance, pension funds, mutual funds, banks) who invested on behalf of other parties $[12 ; 25]$.

- Ultimate Government Ownership

This research operationalizes the ultimate ownership of shares by the government.

3) Effectiveness of the Board of Commissioners and the Audit Committee

For this study, measurement of the role of the commissioners and audit committee employees adopted scoring from Hermawan [26] and Prabowo [27]. Prabowo
[27] adopted the scoring of Hermawan's research [26], adding the latest regulatory adjustments. Using the Template

After the text edit has been completed, the paper is ready for the template. Duplicate the template file by using the Save As command, and use the naming convention prescribed by your conference for the name of your paper. In this newly created file, highlight all of the contents and import your prepared text file. You are now ready to style your paper; use the scroll down window on the left of the MS Word Formatting toolbar.

\section{TABLE I SCORING OF BOARD OF COMMISSIONERS' EFFECTIVENESS}

\section{Independence of the Board of Commissioners}

1.The proportion of independent board members

BI (2013) requires banks to have $50 \%$ independent commissioners. The measurement criteria are:

Good: Over $50 \%$ of members are independent; Fair: Equal to $50 \%$; Poor: Lower than $50 \%$

2.Chairman of BOC is an independent commissioner

Good: Chairman of BOC is an independent commissioner; Poor: Chairman of BOC is not an independent commissioner or no information

3.Independent definition

Good: If the company provides a clear statement of independence, in accord with definitions set by Bank Indonesia (2006) and OJK (2016);

Poor: No independent definition, according to definitions dit etapkan

4.Board tenure

Good: The average number of years commissioners have served is less than 5 years; Fair: $5-10$ years; Poor: Over 10 years

Activities of the Board of Commissioners

5.BOC's duties and responsibilities

Good: Clear statement of BOC duties and responsibilities; Poor: No clear statement of BOC duties and responsibilities

6.Number of meetings in a year

Good: More than 6 ; Fair: 4-6; Poor: Fewer than 4

7.Average level of meeting attendance

Good: More than $80 \%$; Fair: $70 \%-80 \%$; Poor: Fewer than $70 \%$ or no information

8.BOC's report

Good: A report of the commissioners is included in the annual report ; Poor: No report of the commissioners is included in the annual report.

9.BOC evaluates management performance

Good: A statement on management performance is provided by the BOC in the annual report.

Poor: No statement on management performance is provided by the BOC in the annual report.

10.BOC assesses business prospects prepared by management

Good: A statement prepared by management on the evaluation or assessment of business prospects

Poor: No statement is prepared by management on the evaluation or assessment of business prospects

\section{Size of the Board of Commissioners}

11.Number of members of the board of commissioners

Good: 5-10 ; Fair: 11-15; Poor: More than 15 or less than 5

\section{Competence of the Board of Commissioners}

12.Percentage of BOC members with financial or accounting skills

Good: BOC members with a history of education or having worked in accounting or finance exceeds $50 \%$

Fair: $30 \%-50 \%$; Poor: Fewer than $30 \%$ or no information

13.Number of commissioners with business experience

Good: If over $50 \%$ of experienced members of the BOC are included in the company or have been directors of another company

Fair: $30 \%-50 \%$; Poor: Fewer than 30\%

14.The number of BOC members who are very knowledgeable about the company's business

Good: BOC members who have served as a company commissioner for more than 1 year is more than $50 \%$

Fair: $30 \%-50 \%$; Poor: Fewer than 30\%

15. The average age of BOC members

Good: Over 40 years; Fair: $30-40$ years; Poor: Under 30 years

Source: Hermawan [25] and Prabowo [26] 
TABLE II. SCORING OF AUDIT COMMITTEE EFFECTIVENESS

\begin{tabular}{|l|}
\hline Activities, Duties, and Responsibilities of the Audit Committee \\
\hline 1.Review Financial Information \\
\hline 2.Review of compliance with regulations \\
\hline 3.Gives an independent opinion on differences of opinion between \\
management and accountant \\
\hline 4.Recommend the appointment of an external auditor \\
\hline 5.Supervise follow-up on the findings \\
\hline 6.Review of risk management activities \\
\hline 7.Review complaints \\
\hline 8.Advise on potential conflicts of interest \\
\hline 9.Maintain confidentiality of documents, data, and company information \\
For no. 1-9: \\
Good: In the annual report it is stated that the above is the duty of the audit \\
committee; Poor: In the annual report it is not stated that the above is the \\
duty of the audit committee \\
\hline 10.Number of audit committee meetings in 1 year \\
Good: More than 6 times during 1 year, Fair: $4-6$ times during 1 year; \\
Poor: Fewer than 4 times during 1 year \\
\hline 11.Meeting attendance frequency \\
Good: Average percentage of attendance higher than $80 \%$ for a year \\
Fair: Average percentage of attendance $70 \%-80 \%$ for a year \\
Poor: Average percentage of attendance lower than $70 \%$ for a year \\
\hline Audit Committee Size \\
\hline 12.Number of audit committee members \\
Good: More than $3 ;$ Fair: 3 Poor: fewer than 3 \\
\hline Competence of the Audit Committee \\
\hline 13.Accounting or financial ability \\
Good: More than one member has expertise in finance or accounting. \\
Fair: One member has expertise in finance or accounting. \\
Poor: No members have expertise in finance or accounting. \\
\hline 14.Average age \\
Good: Average above 40 years; Fair: Average $30-40$ years; Poor: Average \\
below 30 years \\
\hline Maximum and minimum scores \\
\hline Source: Hermawan [25] and Prabowo [26] \\
\hline
\end{tabular}

Data Analysis

For this research, data were analyzed by panel data regression using the random effect model. Outliers were treated using the winsorization technique, that is, by changing data outliers to the value of the upper and lower limits (mean \pm (3 x standard deviation $)$ ).

\section{RESULTS AND DISCUSSION}

From 2012 to 2016, 31 banking companies were consistently and continuously listed on the IDX (Indonesian Stock Exchange). The selected sample is a banking company that published annual reports from 2012 to 2016 and disclosed its audit fees. Not all companies consistently disclosed audit fees during that period, but overall, there were 107 samples to be studied over the 5-year period. The following are descriptive statistics from the data.

TABLE III. STATISTIC DESCRIPTIVE

\begin{tabular}{|c|c|c|c|c|}
\hline Variable & Mean & Std. Dev & Min & Max \\
\hline AUDFEE(ln) & 21.6112 & 0.9452 & 19.7424 & 23.3046 \\
\hline AUDFEE (million rp) & 3,587 & & 375 & 13,215 \\
\hline CG & 68.3271 & 3.6878 & 58 & 76 \\
\hline SIZE (ln) & 32.0402 & 14.6226 & 29.0273 & 34.5767 \\
\hline SIZE (million rp) & $19,345,779$ & & $4,040,140$ & $1,038,706,009$ \\
\hline NPL & 0.0147 & 0.0121 & 0 & 0.0513 \\
\hline ROA & 0.0188 & 0.0204 & -0.0571 & 0.0962 \\
\hline Variabel Dummy & \multicolumn{2}{|c|}{ Dummy =1 } & \multicolumn{2}{|c|}{ Dummy = 0 } \\
\hline FAMDUM & \multicolumn{2}{|c|}{0.3457} & \multicolumn{2}{c|}{0.5542} \\
\hline INSTDUM & \multicolumn{2}{|c|}{0.4672} & \multicolumn{2}{c|}{0.7102} \\
\hline GOVDUM & \multicolumn{2}{|c|}{0.2897} & \multicolumn{2}{c|}{0.1402} \\
\hline LOSS & \multicolumn{2}{|c|}{0.0561} & \multicolumn{2}{c|}{} \\
\hline BIG4 & \multicolumn{2}{|c|}{0598} & \multicolumn{2}{c|}{} \\
\hline
\end{tabular}

\section{A. Effect of Ultimate Family Ownership on Audit Fee}

Table 4 shows that the FAMDUM variable (ultimate ownership by family) had no significant effect on the audit fee, this result does not prove (H1), that family ownership lowers audit fees. This finding follows those of Ben Ali and Lesage [12] that no relationship exists between family ownership and audit fees, possibly caused by alignment effect and entrenchment effect, which are mutually influential. According to the alignment effect argument, family ownership mitigates agency problems because shareholders (family) and the company (agent) have a harmonious goal, that is, the company's future. However, family ownership, especially a large percentage, can trigger agency problem II, that is, problems between majority and minor shareholders (expropriation). This is in line with the entrenchment effect argument in which expropriation risk might affect audit fees. In addition, risk of earnings management can also improve audit fees. Ding, Zhang, and Zhang [28] stated that large shareholders tended to maximize earnings management for personal gain.

TABLE IV. REGRESSION RESULTS

\begin{tabular}{|c|c|c|c|c|c|}
\hline \multirow{2}{*}{ Variable } & \multirow{2}{*}{ Pred } & \multicolumn{2}{|c|}{ Model 1} & \multicolumn{2}{|l|}{ Model 2} \\
\hline & & Coef & P (z-test) & Coef & P (z-test) \\
\hline FAMDUM & $(+/-)$ & 0.0790 & 0.6170 & -0.0743 & 0.725 \\
\hline INSTDUM & $(+)$ & 0.2136 & $0,0845^{*}$ & 0.0549 & 0.3965 \\
\hline GOVDUM & $(-)$ & -0.1963 & 0.1885 & -0.3711 & $0,0820 * * *$ \\
\hline $\mathrm{CG}$ & $(+)$ & 0.5403 & 0.1760 & 0.2515 & 0.2000 \\
\hline SIZE & $(+)$ & 0.5057 & $0,000 * * *$ & 0.5035 & $0,0000 * * *$ \\
\hline NPL & $(+)$ & 0.3840 & 0.45050 & 1.0731 & 0.3645 \\
\hline ROA & $(-)$ & 0.6135 & 0.3895 & 0.3616 & 0.4355 \\
\hline LOSS & $(+)$ & 0.2643 & $0,0510^{*}$ & 0.2553 & $0,0504 *$ \\
\hline BIG4 & $(+)$ & 0.5912 & $0,0000 * * *$ & 0.6249 & $0,0000^{* * *}$ \\
\hline FAMDUM_CG & $(+)$ & & & -2.9947 & 0.1465 \\
\hline INSTDUM_CG & $(-)$ & & & -2.2318 & 0.2180 \\
\hline GOVDUM_CG & $(+)$ & & & 0.3349 & 0.4585 \\
\hline \multicolumn{6}{|l|}{ Obs. $=107$} \\
\hline \multicolumn{2}{|c|}{ Prob $>$ chi 2} & \multicolumn{2}{|l|}{0} & \multicolumn{2}{|l|}{0} \\
\hline \multicolumn{2}{|c|}{$\begin{array}{l}\text { R-Square } \\
\text { effect) }\end{array}$} & \multicolumn{2}{|l|}{0.8673} & \multicolumn{2}{|l|}{0.8772} \\
\hline \multicolumn{6}{|c|}{ Independent Variable $=$ Audit fee (In) } \\
\hline
\end{tabular}

\section{B. Effect of Institutional Ownership on Audit Fee}

The next variable, INST, is the variable dummy of institutional ownership. This variable has a positive coefficient, that is, equal to 0.2136 , and has a significant influence at the $10 \%$ level. Institutional investors increase audit fees in accordance with $\mathrm{H} 2$ and with Ben Ali and Lesage [12]; institutional ownership positively affects audit fees. Institutional investors demand quality external audits as a form of investor protection. According to signaling theory, institutional investors signal to third-party fund owners that the company is performing well through a good external audit, thus raising the audit fee. Investors need external assurance of accurate information and the absence of expropriation so that external audit requests rise.

\section{Effect of Government Ownership on Audit Fee}

Another independent variable is GOV, a dummy variable of governmental ownership. Table 4 shows this variable's significant influence at the $10 \%$ level, a coefficient of - 
0.3711 in model 2 , where there are moderating variables. The coefficient indicates a negative relationship between government ownership and audit fees in accordance with $\mathrm{H} 3$ and Ben Ali and Lesage [12], that is, government ownership suppresses audit fees. Government ownership increases company control (alignment effect) because the government has incentives to be active in conducting surveillance. If the government fails to protect the company's reputation, it experiences losses-in-reputation costs. Effective government oversight improves the company's internal control and reduces company risk so as to suppress the audit effort and lower the audit fee.

\section{Effect of the Board of Commissioners and the Audit Committee on Ownership and Audit Fee}

Table 4 shows that not all moderating variables have significant effect on ownership and audit fee relationshipswhether family, institutional, or government ownership. In other words, the supervisory role of the board of commissioners and the audit committee still cannot influence the relationship, and their supervision can be replaced by shareholders. The supervisory role of the audit committee and the commissioners are limited to mandatory functions. Moreover, in the banking industry, companies are already highly supervised by BI and OJK

\section{E. Control Variables}

Of the five other control variables related to company characteristics included in this study, only three had positive and significant influence, i.e., SIZE, LOSS, and BIG4, at the $1 \%$ significance level. Representing the company's size, losses, and audits by the Big 4, these variables influenced audit fees in accord with the original prediction. The larger the company, the greater the audit procedures' complexity and scope of work required, so the higher the audit fee.

The LOSS variable positively affected the audit fee at a significance level of $10 \%$, in accord with the original prediction and in line with $\mathrm{Wu}$ [29]. Companies experiencing losses desire to show externally that the company is still running well. The company tries to make efforts so that losses experienced will not meet the view of various parties, one of them by increasing the audit fee.

The BIG4 variable also had positive and significant effect at the $1 \%$ significance level because, of course, these internationally known and well respected firms charge more than non-Big 4 auditors.

Meanwhile, the other two control variables, NPL and ROA, had no significant effect on any models.

\section{CONCLUSION AND IMPLICATIONS}

This study examined the effect of ultimate ownership on audit fees of banking company listed on the IDX from 2012 to 2016, and tested whether the effectiveness of the board of commissioners and audit committee can weaken or strengthen relationships between ultimate ownership and audit fees.

This study found that ultimate family ownership had no significant effect on the company's audit fee, probably due to the alignment effect and entrenchment effect. Family ownership mitigates type I of the agency problem and lowers audit fees. However, family ownership, especially a large percentage, can trigger type II of agency problem between the majority and minor shareholders (expropriation), thus increasing the audit fee. Because of these positive and negative influences, the total effect is negated.

Institutional investors as ultimate owners increase audit fees by demanding high quality for external audits as a form of investor protection. According to signaling theory, institutional investors signal third-party fund owners that the company is performing well through a good external audit, thus raising the audit fee.

Government ownership had a significant negative effect on audit fees when there were moderating variables. Government ownership increases company control (alignment effect) because the government has incentives to be active in conducting surveillance. If the government fails to protect the company's reputation, it experiences loss-ofreputation costs.

Not all moderating variables had significant effect on ownership and audit fee relationships - whether family, institutional, or government ownership. The supervisory role of the board of commissioners and audit committee was unable to influence the relationship, and shareholders can replace their supervision. The supervisory role of the audit committee and commissioners are limited to what is mandatory. Moreover, in the banking industry, companies are already highly supervised by BI and OJK.

This study has several limitations, which should be considered for further research. The study used only banking companies consistently listed on the IDX from 2012 to 2016. Therefore, the authors suggest conducting broader research on both listed and non-listed banks for more representative results.

Moreover, not all companies disclose their audit fees in annual reports. Future research should gather complete audit fee data to reflect research results better by using other methods, for instance, direct requests to public accounting firms or to the Pusat Pembinaan Profesi Keuangan (P2PK).

In measurement of audit committee effectiveness, committee members' legal and banking expertise should be considered because the BI regulation (2013) on implementation of GCG for commercial bank audits requires committee competence not only in finance but also in legal or banking capability. Suggestions for further research are to measure audit committee members' ability in law and banking to describe better the committee's competence.

\section{ACKNOWLEDGMENT}

We gratefully acknowledge financial support from Research Grant from Universitas Indonesia.

\section{REFERENCES}

[1] Jensen, M. C., \& Meckling, W. H. (1976). Theory of the firm: Managerial behavior, agency costs and ownership structure. Journal of Financial Economics, 3(4), 305-360. doi: 10.1016/0304405X(76)90026-X.

[2] Villalonga, B., \& Amit, R. (2006). How do family ownership, control and management affect firm value? Journal of Financial Economics, 80(2), 385-417. doi: 10.1016/j.jfineco.2004.12.005.

[3] Claessens, S., Djankov, S., \& Lang, L. H. P. (2000). The separation of ownership and control in East Asian Corporations. Journal of Financial Economics, 58(1-2), 81-112. doi: 10.1016/S0304405X(00)00067-2. 
[4] Wang, D. (2006). Founding family ownership and earnings quality. Journal of Accounting Research, 44(3), 619-656. doi: 10.1111/j.1475-679X.2006.00213.x

[5] La Porta, R., Lopez-de-Silanes, F., Shleifer, A., \& Vishny, R. (2000). Investor protection and corporate governance. Journal of Financial Economics, 58(1-2), 3-27. doi: 10.1016/S0304-405X(00)00065-9.

[6] Khan, A., Muttakin, M. B., \& Siddiqui, J. (2015). Audit fees, auditor choice and stakeholder influence: Evidence from a family-firm dominated economy. The British Accounting Review, 47(3), 304320. doi: 10.1016/j.bar.2015.03.002.

[7] Ali, A., Chen, T. Y., \& Radhakrishnan, S. (2007). Corporate disclosures by family firms. Journal of Accounting and Economics, 44(1-2), 238-286. doi: 10.1016/j.jacceco.2007.01.006.

[8] Darmadi, S. (2016). Ownership concentration, family control, and auditor choice. Asian Review of Accounting, 24(1), 19-42. doi: 10.1108/ARA-06-2013-0043

[9] Ali, C. B., \& Lesage, C. (2014). Audit fees in family firms: Evidence from U.S. Listed companies. Journal of Applied Business Research, $30(3), 807$

[10] Mitra, S., Hossain, M., \& Deis, D. R. (2007). The empirica relationship between ownership characteristics and audit fees. Review of Quantitative Finance and Accounting, 28(3), 257-285. doi: 10.1007/s11156-006-0014-7

[11] Alqadasi, A., \& Abidin, S. (2017). The effectiveness of internal corporate governance and audit quality: The role of ownership concentration-Malaysian evidence. The International Journal of Business in Society, 18(2), 233-253

[12] Ben Ali, C. B., \& Lesage, C. (2013). Audit pricing and nature of controlling shareholders: Evidence from France. China Journal of Accounting Research, 6(1), 21-34. doi: 10.1016/j.cjar.2012.08.002

[13] Nelson, S. P., \& Mohamed-Rusdi, N. F. (2015). Ownership structures influence on audit fee. Journal of Accounting in Emerging Economies, 5(4), 457-478.

[14] Hay, D. C., Knechel, W. R., \& Wong, N. (2006). Audit fees: A metaanalysis of the effect of supply and demand attributes. Contemporary Accounting Research, 23(1), 141-191. doi: 10.1506/4XR4-KT5VE8CN-91GX

[15] Collier, P., \& Gregory, A. (1999). Audit committee activity and agency costs. Journal of Accounting and Public Policy, 18(4-5), 311332 .

[16] O'Sullivan, N. (2000). The impact of Board Composition and Ownership on Audit Quality: Evidence from Large UK companies. British Accounting Review, 32(4), 397-414. doi: 10.1006/bare.2000.0139.

[17] Goodwin-Stewart, J., \& Kent, P. (2006). Relation between externa audit fees, audit committee characteristics and internal audit Accounting and Finance, 46(3), 387-404. doi: 10.1111/j.1467629X.2006.00174.x.
[18] Carcello, J. V., Hermanson, D. R., Neal, T. L., \& Riley,Richard A.,,Jr. (2002). Board characteristics and audit fees. Contemporary Accounting Research, 19(3), 365-384.

[19] Boo, E., \& Sharma, D. (2008). The association between corporate governance and audit fees of bank holding companies. Corporate Governance: The International Journal of Business in Society, 8(1), $28-45$.

[20] Lifschutz, S., Jacobi A., \& Feldshtein, S. (201-0). Corporate Governance Characeteristics and External Audit Fees: A Study of Large Public Companies in Israel International Journal of Business and Management, 5(3), 109

[21] Chen, A., Kao, L., Tsao, M., \& Wu, C. (2007). Building a corporate governance index from the perspectives of ownership and leadership for firms in Taiwan. Corporate Governance: An International Review, 15(2), 251-261.

[22] Abdallah, A. A., \& Ismail, A. K. (2017). Corporate governance practices, ownership structure, and corporate performance in the GCC countries. Journal of International Financial Markets, Institutions \& Money, 46, 98-115.

[23] La Porta, R., Lopez-de-Silanes, F., \& Shleifer, A. (1999). Corporate ownership around the world. Journal of Finance, 54(2), 471-517. doi: 10.1111/0022-1082.00115.

[24] Arifin, Z. (2003). Masalah Agensi dan Mekanisme Kontrol pada Perusahaan dengan Struktur Kepemilikan Terkonsentrasi yang di Kontrol Keluarga: Bukti dari Perusahaan Publik. Disertasi Pascasarjana, Fakultas Ekonomi. Universitas Indonesia. Depok.Indonesia

[25] Khan, A. R., Hossain, D. M., \& Siddiqui, J. (2011). Corporate ownership concentration and audit fees: The case of an emerging economy. Advances in Accounting, 27(1), 125-131. doi: 10.1016/j.adiac.2011.04.007.

[26] Hermawan, A. A. (2011). The influence of effective Board of Commissioners and Audit Committee on the Informativeness of Earnings: Evidence from Indonesian listed firms. Asia Pacific Journal of Accounting and Finance, 2(1), 1-38

[27] Prabowo, Y. R. \& Fitriany, F. (2018). Effect of Whistle Blowing System and Code of Ethics to The Quantity of The Fraud Case That Reported: Study on Banking in Indonesia, Proceedings of the Third Asia-Pacific Research in Social Sciences and Humanities (APRiSH) Conference, Jakarta, Indonesia

[28] Ding, Y., Zhang, H., \& Zhang, J. (2007). Private vs State Ownership and Earnings Management: Evidence from Chinese listed companies. Corporate Governance, 15(2), 223-238. doi: 10.1111/j.14678683.2007.00556.x

[29] Wu, X. (2012). Corporate governance and audit fees: Evidence from companies listed on the Shanghai Stock Exchange. China Journal of Accounting Research, 5(4), 321-342.

[30] Collier, P., \& Gregory, A. (1999). Audit committee activity and agency costs. Journal of Accounting and Public Policy, 18(4-5), 311332. 